\title{
The effect of tamoxifen on IGF signaling pathway in the mouse ovary
}

\author{
Ender Deniz ASMAZ ${ }^{a}$, Berrin ZIK ${ }^{b, \bowtie}$ \\ Uludağ University, Faculty of Veterinary Medicine, Department of Histology and Embryology, Bursa, Turkey. \\ aORCID: 0000-0001-6468; ' 'ORCID: 0000-0002-1053-6250.

${ }^{凶}$ Corresponding author: e-mail: bzik @ uludag.edu.tr
Received date: 14.01.2019- Accepted date: 23.05.2019

\begin{abstract}
Tamoxifen (TAM) is one of selective estrogen receptor modulators used in breast cancer treatment and prevention. The objective of this study was to determine whether or not insulin-like growth factor-I (IGF-1) and its receptor (IGF-1R), has any role in the effect mechanism of TAM on the ovary. Experimentally, animals were divided into three groups as control group ( $\mathrm{n}=20$ ), low dose TAM treatment group $(0.5 \mathrm{mg} / \mathrm{mouse} / \mathrm{day}, \mathrm{n}=20)$ and high dose TAM treatment group $(1.5 \mathrm{mg} / \mathrm{mouse} / \mathrm{day}, \mathrm{n}=20)$. TAM was injected 0.5 and $1.5 \mathrm{mg} / \mathrm{mouse} /$ day for 5 days. Ovarian sections were used to examine the general structure by trichrome staining method and to determine IGF-1 and IGF-1R expressions by immunohistochemical staining method. After the experiment, the presence of atretic follicles and small cystic structures in the TAM-treated animals was determined. Also, antral follicles and the corpus luteum were much less in the high dose TAM group than in the control. TAM did not change the expression of IGF-1 in granulosa cells, but increased the expression of IGF-1R. In TAM groups, IGF-1 and IGF-1R expression were increased in oocytes of follicles and in interstitial cells depending on TAM doses. However, while IGF-1 expression was unchanged in the corpus luteum, decreased in treatment group. TAM generally stimulated IGF-1 and IGF-1R expression in a dose-dependent manner. The results suggest that IGF1 signaling pathway is involved in the mechanism of action of TAM on the ovary. We may assert that it may be useful to use IGF-1 signaling pathway regulators to adjust the effects of TAM on the ovary.
\end{abstract}

Keywords: IGF-1, IGF-1R, mouse, ovary, reproduction, tamoxifen.

\section{Fare ovaryumunda tamoxifenin IGF-1 sinyal yolağı üzerine etkisi}

Özet: Tamoksifen (TAM), meme kanseri tedavisinde ve önlenmesinde kullanılan seçici östrojen reseptörü modülatörlerinden biridir. Sunulan çalışmanın amacı, ovaryum üzerine TAM'ın etki mekanizmasında, insülin benzeri büyüme faktörü-I (IGF-1) ve reseptörünün (IGF-1R) herhangi bir rolünün olup olmadığını belirlemektir. Deney hayvanları, kontrol grubu (n=20), düşük doz TAM uygulanan grup $(0.5 \mathrm{mg} /$ fare/gün, $\mathrm{n}=20)$ ve yüksek doz TAM uygulanan grup $(1.5 \mathrm{mg} /$ fare/gün, $\mathrm{n}=20)$ olmak üzere üç gruba ayrıldı. TAM enjeksiyonu 0.5 ve $1.5 \mathrm{mg} /$ fare/gün olmak üzere 5 gün boyunca uyguland. Ovaryum kesitlerine, genel yapıyı incelemek için trikom boyama, IGF-1 ve IGF-1R'in ekspresyonlarını belirlemek için immunohistokimyasal yöntem uygulandı. Deney sonrasında, TAM uygulanan hayvanlarda atretik foliküller ve küçük kistik yapıların varlığı belirlendi. Bununla beraber, yüksek doz TAM grubunda, antral foliküller ve korpus luteum, kontrol grubuna göre daha azdı. Granüloza hücrelerinde TAM, IGF-1'in ekspresyonunu değiştirmezken, IGF-1R'nün ekspresyonunu arttırdı. TAM, folliküllerin oositlerinde ve doza bağlı olarak intersitisyel hücrelerde IGF1 ve IGF-1R expresyonunu arttırdı. Bununla birlikte deney grubunun korpus luteumunda IGF-1 ekspresyonu değişmezken, IGF-1R ekpresyonu azaldı. Genel olarak TAM doza bağlı, IGF-1 ve IGF-1R ekspresyonlarını uyardı. Bu sonuçlar, ovaryum üzerine TAM'ın etki mekanizmasına IGF-1 sinyal yolağının dahil olduğunu göstermektedir. Tamoksifen'in ovaryum üzerindeki etkilerinin düzenlenmesinde, IGF-1 sinyal yolağı regülatörlerinin kullanılmasının yararlı olabileceğini düşünmekteyiz.

Anahtar sözcükler: Fare, IGF-1, IGF-1R, ovaryum, tamoxifen, üreme.

\section{Introduction}

Tamoxifen (TAM) is a nonsteroidal triphenylethyl compound belonging to the class of selective estrogen receptor modulators (SERMs) that bind to estrogen receptors (ERs) and exhibit estrogenic or antiestrogenic effects depending on the target tissue $(17,24)$. At present, TAM is one of the most widely used drugs in breast cancer treatment (13). IGF-1 and IGF-1R are important factors in cell proliferation, cell differentiation, follicular development and ovulation $(4,5,44)$. IGF-1/IGF-1R acts as modulators of gonadotropins at the cellular level as well as stimulating granulosa and theca cell proliferation and differentiation (4). Also, IGFs is involved to the synthesis of both estradiol and progesterone (16). The ovary is a major site of hormone-regulated IGF-1 production in mammalians (37). TAM can modulate the IGF-1/IGF-1R 
system in different tissues by making a direct regulatory effect on IGF-1 secretion $(26,29)$. Furthermore, TAM has been shown to have a radioprotective effect and to prevent follicle loss, through increasing the local IGF-1 level (18). Also, TAM administration increases gonadotropin stimulation in ovarian follicles and causes hyperestrogenic effect (31). On the other hand, TAM causes formation of persistent follicular cysts in the premenopausal women $(7$, 22,32 ) and increase of IGF-1 expression in interstitial cells has been directly related to the polycystic ovary syndrome (30). It was reported that TAM administration in ovarian and ER positive breast cancer models prevents breast cancer but was not effective on experimental ovarian cancer (36).

Nevertheless, there was not a sufficient number of studies on the role of IGFs in the mechanism of action on ovaries of TAM. The aim of this study is to determine whether or not IGFI signaling pathway has any a role in the effect mechanism of TAM on the ovary.

\section{Material and Methods}

Experimental protocol of animals: Sixty mature (8 week old) female inbred BALB/C mice obtained from the Experimental Animals Breeding and Research Center, Uludag University, Turkey, were used throughout the experiments. The experimental animals were examined under controlled conditions with humidity of $60-70 \%$ and 12 hourlight / 12 hour dark cycle at a temperature of 20$24^{\circ} \mathrm{C}$ with 5 experimental animals per cage. Feed and water were provided ad libitum throughout the experimental period. The experimental protocols were approved by the Animal Care and Use Committee of the Uludag University and were in accordance with the National Institute of Health Guide for the Care and Use of Laboratory Animals (2012- 09/04).

Mice were randomly divided into 3 groups. The first treatment group (0.5 TAM group, $n=20)$ was injected subcutaneously (s.c.) $0.5 \mathrm{mg} / \mathrm{mouse} /$ day with TAM dissolved in 10\% ethanol: $90 \%$ corn oil. The other treatment group (1.5 TAM group, $n=20$ ) was injected (s.c.) $1.5 \mathrm{mg} / \mathrm{mouse} /$ day with dissolved TAM. Control group mice $(n=20)$ were injected (s.c.) daily with only 10\% ethanol: $90 \%$ corn oil (vehicle). The dissolved TAM and vehicle were injected for 5 days in a total of $0.1 \mathrm{ml}$ s.c. to the animals (23). TAM was freshly prepared everyday before injection. At the end of the treatment the animals were euthanized under inhalation anesthesia and abdomens were opened. The ovaries were fixed with $10 \%$ neutral buffered formalin. The ovaries were used routine histological procedures and embedded in paraffin and blocked. Five $\mu \mathrm{m}$ thick sections were obtained from the paraffin blocks and cuts were taken to lysine slides. After deparaffinization and rehydration, sections were stained with immunohistochemistry for IGF-1 and IGF-1R expression and with Crossman's modified trichrome stain (8) for ovary morphology.

Reagents: Antibodies against IGF-1 (G-17) (sc1422) and IGF-1R (C-20) (sc-713) were purchased from Santa Cruz Biotechnology (Santa Cruz, CA). Secondary antibody, ImmPRESS anti goat Ig Peroksidaz (MP-7405) and ImmPRESS anti rabbit Ig Peroksidaz (MP-7401) were purchased from Vector laboratories. DAB (3-3 Diaminobenzidin) (Steady DAB/Plus (ab103723).

Immunohistochemical analysis: The standard streptavidin biotin peroxidase complex technique was applied. For antigen retrieval, the boiling step was performed in a microwave oven of $750 \mathrm{~W}$ with sodium citrate buffer (1 M, pH 6.1) for $3 \times 5$ minutes. After the sections were washed with PBS, the sections blocked for 10 minutes for endogenous peroxidase activity. To reduce nonspecific antibody binding, horse serum was applied to sections for $20 \mathrm{~min}$. After that sections were incubated overnight $4^{\circ} \mathrm{C}$ with anti IGF-1 primary antibody diluted $1: 150$ and anti IGF-1R primary antibody diluted 1:100 as recommended by manufacturer. Samples were then washed three times with PBS and incubated with ImmPRESS reagent for $30 \mathrm{~min}$ at room temperature. After washing again with PBS for 3 to 5 minutes, the tissues were washed with distilled water and incubated with 5 minutes DAB for imaging. Hematoxylin was used as counterstaining. Sections were cleared with xylol and covered with the entellan. Negative controls were incubated with the antibody diluent without using the primary antibody. The intensity and localization of IGF-1 and IGF-1R expressions were assessed by two independent observers with scoring system: 0, no immunoreaction; 1, weak immunoreaction; 2, moderate immunosuppression; 3, strong immunoreaction (10).

Follicle classification: Primordial follicle (PO) contains single-layered squamous pre-granulosa cells and at maximum one cubic granulosa cell. Primary follicle (PR) contains single-layer with two or more cubic granulosa cells. Secondary follicle (S) contains two or three-layer cubic granulosa cells. Pre-antral follicle (PA) contains more than three layers of granulosa cells, and antrum is not formed. Antral follicle (A) contains the multi-layered granulosa cells and the antrum is formed.

Statistical analysis: Among the experimental and control groups, IGF-1 and IGF-1R expressions were investigated by using the non-parametric Kruskal Wallis test. The Mann-Whitney $U$ test was used to analyze statistical significance between two groups. Symbols were used for showing confidence level $(P<0.5, P<0.001)$. Statistical analysis of the study was performed using SPSS 23.0 (Statistical Package for Social Sciences). 


\section{Results}

Ovarian histology: In the both 0.5 and 1.5 TAM groups, it was observed that the cortex and medulla distinction on the ovary was distinctive and the interstitial area was wide (Figure 1b, 1c). Especially antral follicles were less in treatment groups than control group (Figure 1a, 1b, 1c). Furthermore, it was determined that the corpus luteum was very few in the ovarium depending on doses of TAM. In addition to, especially the presence of cystic structures and atretic follicles were observed in the medulla region of the experimental groups (Figure 1d).

IGF-1 expression: IGF-1 expression was observed in oocyte cytoplasm of all follicles, granulosa and ten cells, interstitial cells and corpus luteum (Figure 2). Immunohistochemical IGF-1 scores in the ovarian of groups are presented in Figure 3. In general, IGF-1 immunoreactions changed from weak to moderate in the oocytes cytoplasma of the all follicle stages. Statistical significance was determined in preantral follicle oocytes of all groups $(\mathrm{P}<0.001 ; \mathrm{P}<0.05)$ (Figure 3a). In granulosa cells, IGF-1 expression was weak in all follicle stages of all groups (Figure 2). No statistical significance was found between groups (Figure 3b). IGF-1 expression in interstitial cells increased after high dose TAM administration $(\mathrm{P}<0.001 ; \mathrm{P}<0.05)$ (Figure 2b, 2c, 2d, 3c). However, in theca cells were determined a weak expression in the all groups $(\mathrm{P}>0.05)$ (Figure 2c). IGF-1 expression in corpus luteum changed from weak to moderate in the all groups $(\mathrm{P}>0.05)$ (Figure 2b, 2c, 3c).

IGF-1R expression: IGF-1R expression was detected in the oocytes and granulosa cells of all follicles stages, intersititial cells, and corpus luteum (Figure 4a). Immunohistochemical IGF-1R scores in the ovarian of groups are presented in Figure 5. For oocytes cell staining, the strongest immunoreactions were observed in the treatment groups. IGF-1R immunreaction in the oocyte of the all follicles except for primordial and secondary follicles was significantly increased in the treatment compared to control group $(\mathrm{P}<0.05)$ (Figure 5a).
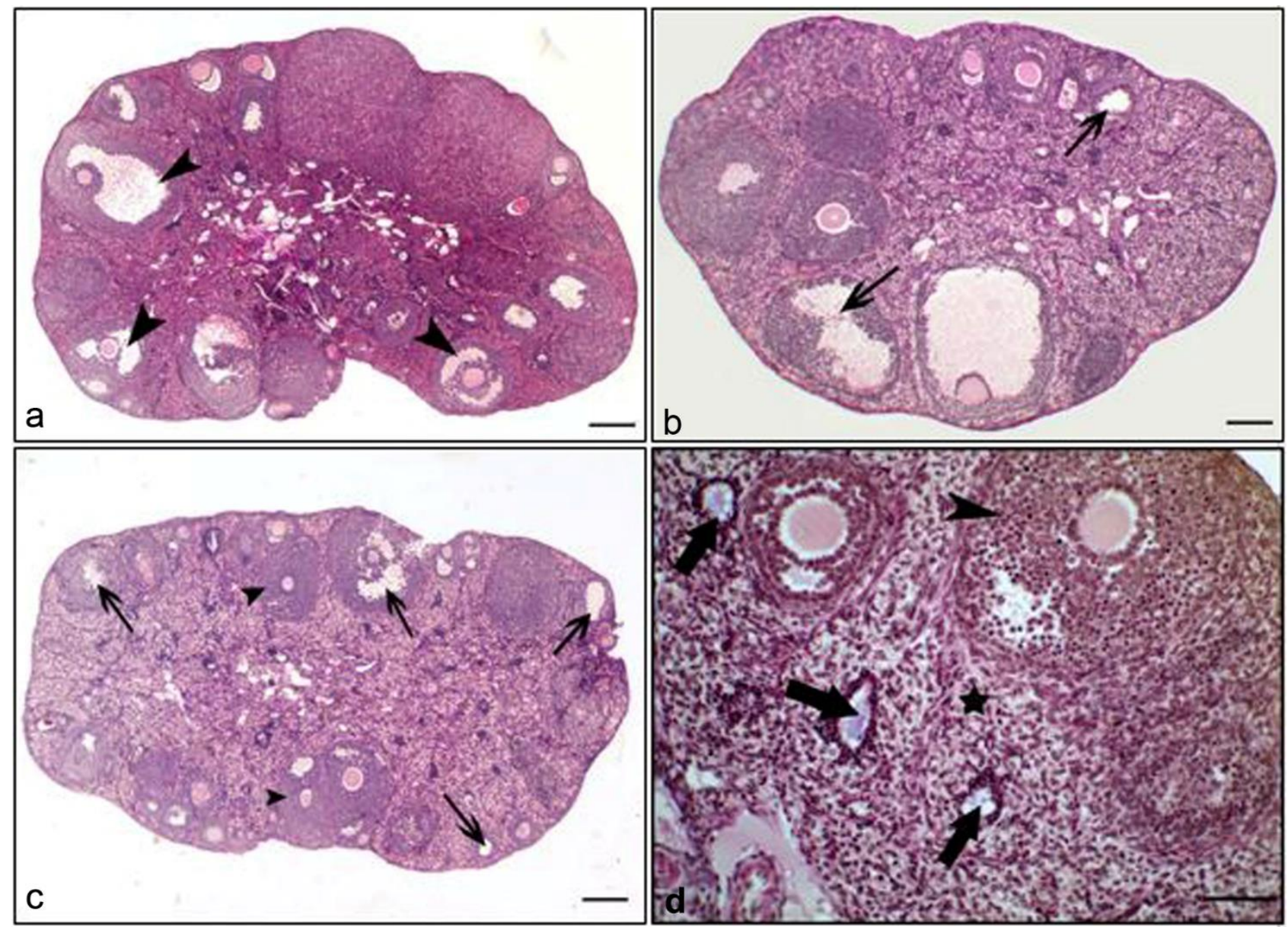

Figure 1. Ovarian histology in control and treatment groups. (a) Control group, (b) Low dose (0.5 TAM) treatment group, (c-d) High dose (1.5 TAM) treatment group. Healthy follicles (arrow head), cystic structures (thick arrows), atretic follicles (thin arrows), interstitial cells (star). Bar (a,b,c) $25 \mu \mathrm{m}$., (d) $50 \mu \mathrm{m}$. 

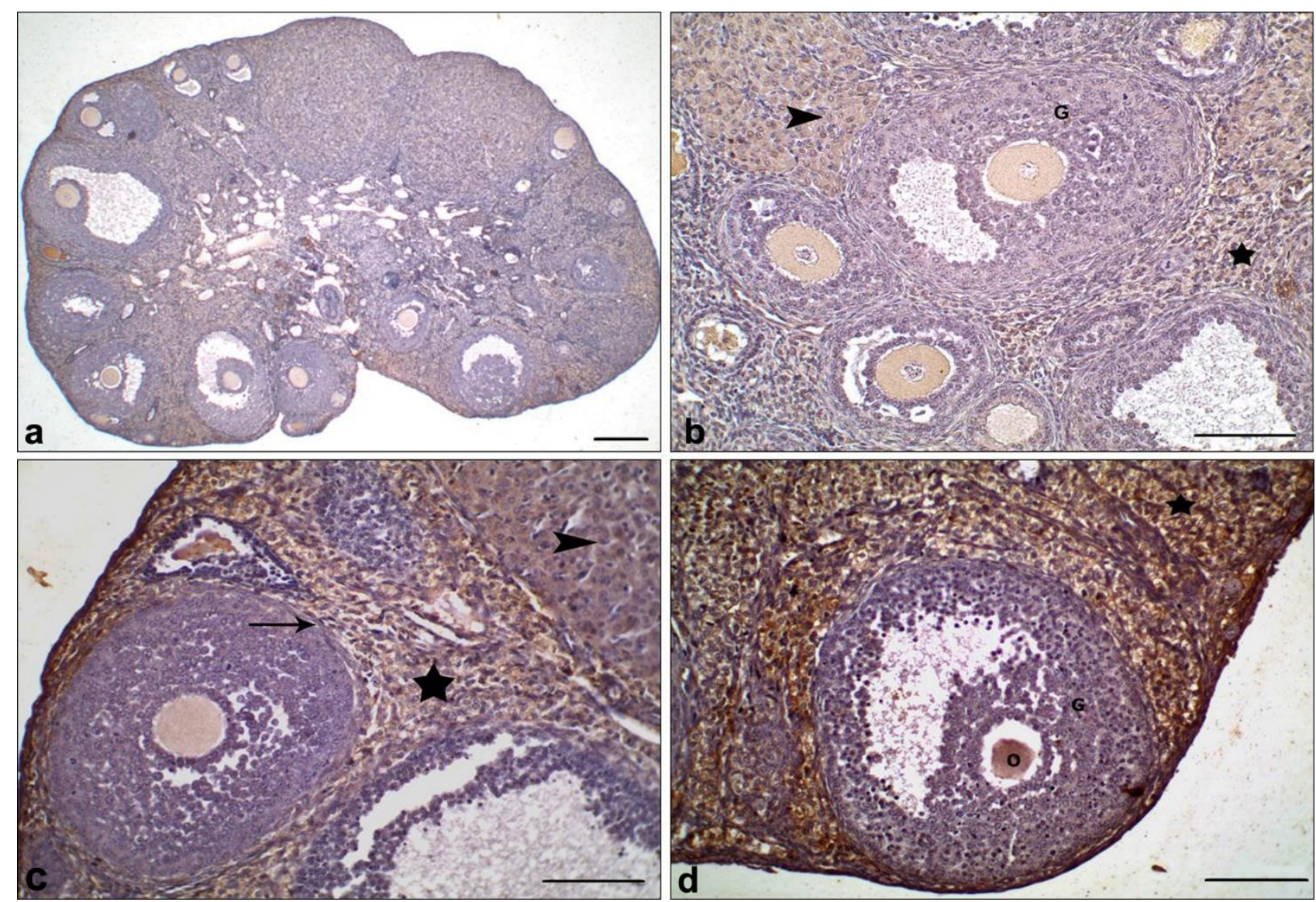

Figure 2. IGF-1 expression in ovaries of control and treatment groups; (a-b) Control group, (c) Low dose (0.5 TAM) treatment group, (d) High dose (1.5 TAM) treatment group. Oocyte (O), granulosa cell (G), corpus luteum (arrow heads ), interstitial cells (stars), theca cells (arrow). Bar: (a) $25 \mu \mathrm{m}$., (b,c,d) $200 \mu \mathrm{m}$.
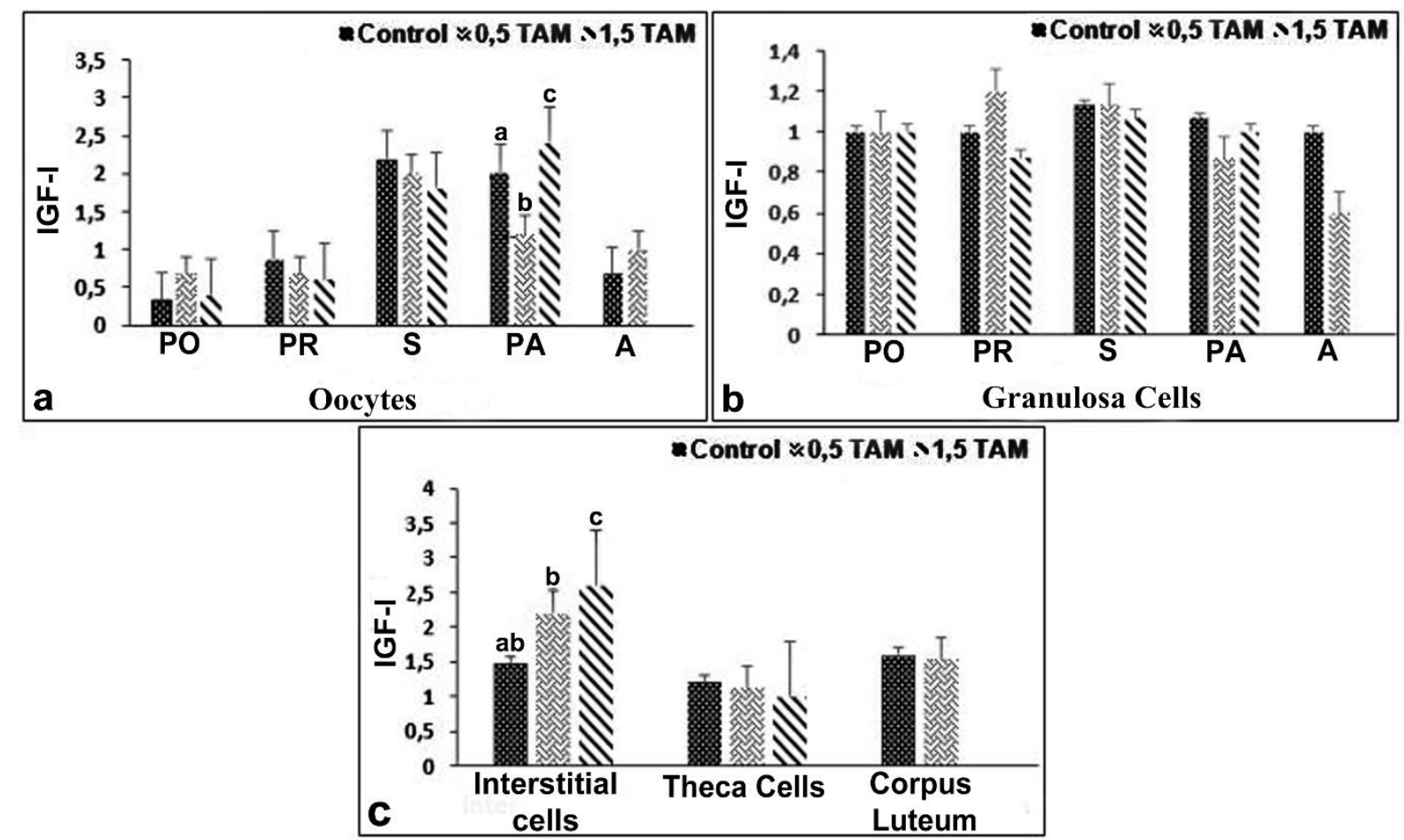

Figure 3. IGF-1 immunoreactivity in (a) oocytes, (b) granulosa cells, (c) interstitial cells, theca cells, and corpus luteum. Primordial follicle (PO), Primary follicle ( PR), Secondary follicle (S), Pre-antral follicle (PA), Antral follicle (A). Different letters indicate statistically significant between groups. 

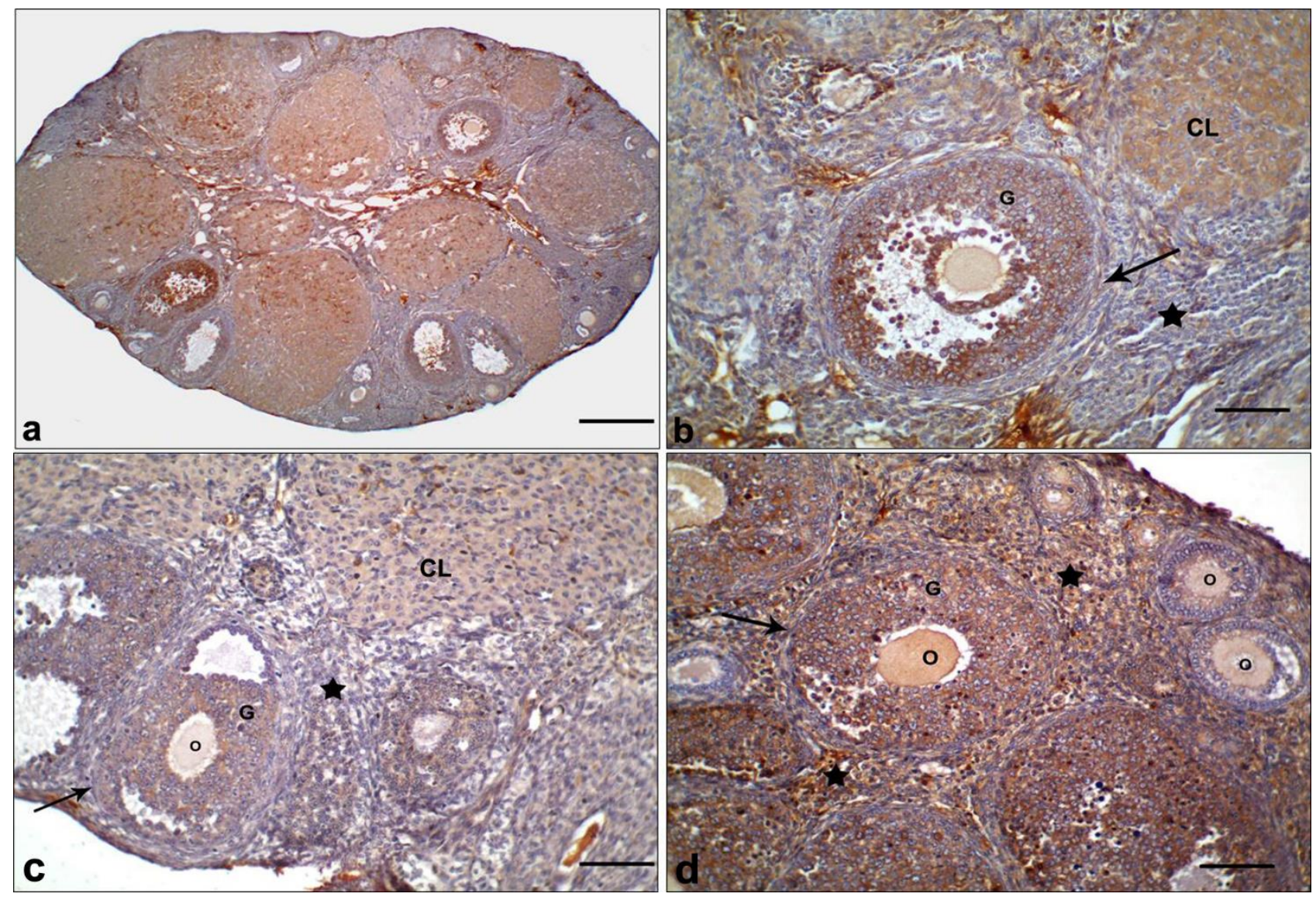

Figure 4. IGF-1R expression in ovaries of control and treatment groups; (a-b) Control group, (c) Low dose (0.5 TAM) treatment group, (d) High dose (1.5 TAM) treatment group. Oocyte (O), granulosa cell (G), corpus luteum (CL), interstitial cells (stars), theca cells (arrows). Bar: (a) $50 \mu \mathrm{m}$. , (b,c,d) $100 \mu \mathrm{m}$.
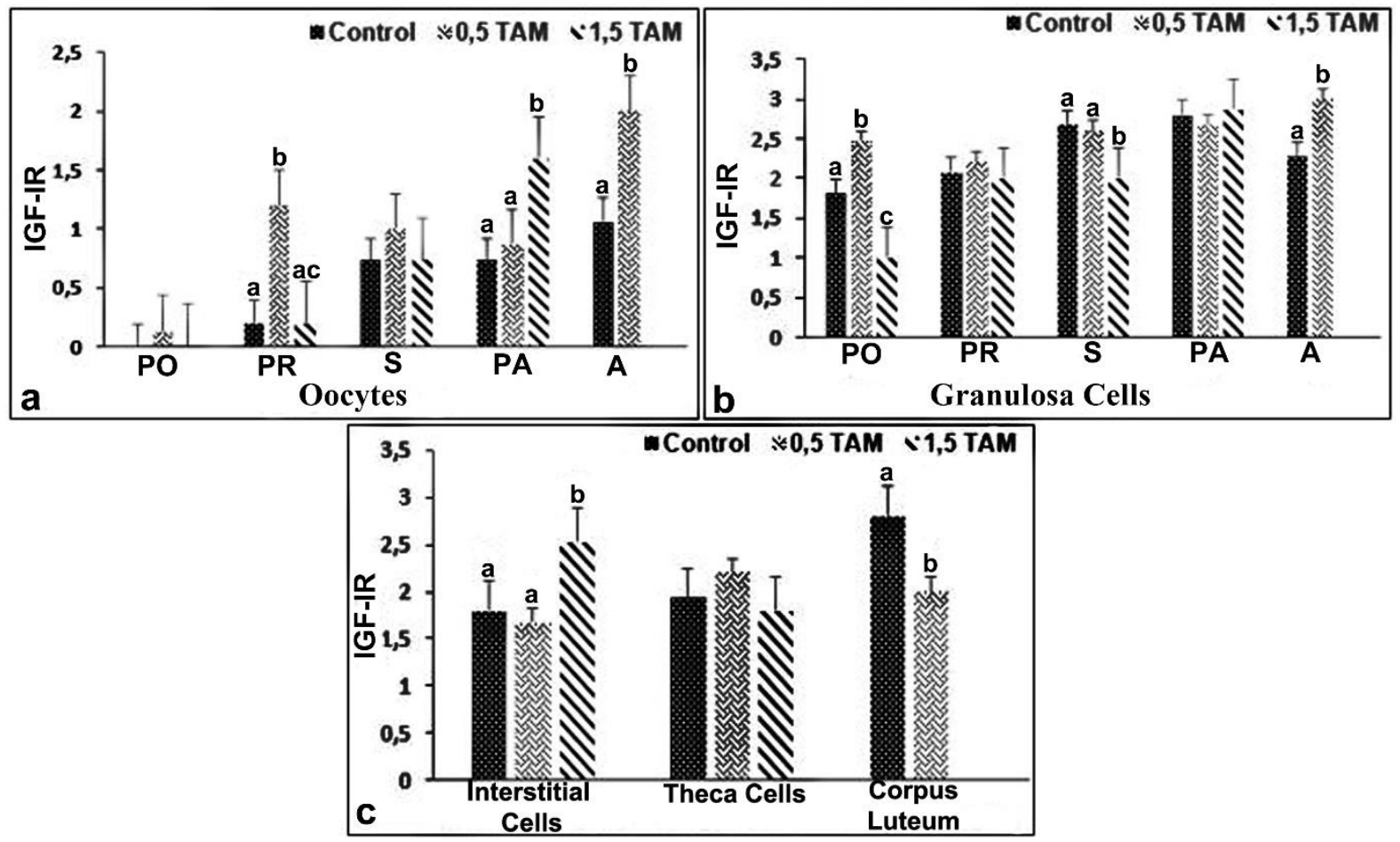

Figure 5. IGF-1R immunoreactivity (a) oocytes, (b) granulosa cells, (c) interstitial cells, theca cells, and corpus luteum. Primordial follicle (PO), Primary follicle ( PR), Secondary follicle (S), Pre-antral follicle (PA), Antral follicle (A). Different letters indicate statistically significant between groups. 
IGF-1R expression was increased moderate to strong depending on follicle development in granulosa cells. Statistical significance was determined in granulosa cells of primordial, secondary and antral follicles between experimental and control groups $(\mathrm{P}<0.001 ; \mathrm{P}<0.05)$ (Figure 5b). The strongest immunoreactions were observed in granulosa cells of the antral follicles of the low dose treatment groups $(\mathrm{P}<0.001)$ (Figure 5b). Due to there are not enough antral follicles in the high dose TAM groups, so it couldn't be evaluated. IGF-1R expression in both theca cells and interstitial cells was showed weak to moderate reaction in all groups. IGF-1R expression in intersititial cells was significantly increased in the high dose treated group compared to the other groups $(\mathrm{P}<0.05)$ (Figure 4d, 5c). Expression of IGF-1R in corpus luteum showed moderate to strong reaction. IGF-1R immunoreactions in corpus luteum were significantly decreased in the treatment group compared to the control group $(\mathrm{P}<0.05)$ (Figure 4b, 4c, 5c). There are not observed enough corpus luteum in the high dose TAM group, so it couldn't be evaluated.

\section{Discussion and Conclusion}

In the present study, we observed the presence of small cystic structures in the interstitial area in the TAM administered groups. However, cortex-medulla distinction was not apparent in the control group and all follicles were seen to be spread across the ovarian surface. Furthermore, we found that the corpus luteum and antral follicles were fewer in the TAM administered groups compared to the control group. Also the atretic follicles were abundant in treatment groups. In agreement with our study, Tsujioka et al. (40) reported that TAM induces large atretic follicles, increases interstitial space and decreases corpus luteum in female mice. Similarly, Akduman et al. (1) also found that after TAM administration, the numbers of corpus luteum and antral follicles decreased significantly compared to the control group and that the atretic follicles increased significantly but the follicle reserve was not affected. Also, Tucker et al. (41) reported that cystic structures were increased in female mice treated with 5 and $50 \mathrm{mg} / \mathrm{kg}$ TAM.

We also examined the protein expression of IGF-1 and IGF-1R in ovarian sections in order to determine whether the IGF signaling pathway could have a role in TAM's effect on the ovary. In the present study, expression of IGF-1 was detected in the oocyte cytoplasm, granulosa cells and theca cells of all follicles stages, interstitial cells and corpus luteum in control group. However, IGF- I immunoreactivity could not be assessed in antral follicle and corpus luteum in the high-dose TAM group, as these structures were not detected in this group, consistent with other studies $(1,40)$. In our study, weak IGF-1 immunoreactivity was observed in the granulosa cells of all groups, as in other studies $(3,21,42,33)$. In granulosa cells, IGF-1 expression decreased in the preantral and antral follicle of low dose TAM group, but no statistically significant were observed between the groups. Similar to our study, Akkaya et al. (2) reported that Metoxychloride, an endocrine disrupting pesticide, also reduced the expression of IGF-1 in granulosa cells of secondary follicles, preantral follicles and antral follicles. Mahran et al (18) have documented the molecular mechanisms of the radioprotective effect of TAM. When injected sc with either corn oil or TAM starting 3 days before irradiation and lasting 3 days after irradiation, TAM has been shown to have a radioprotective effect and to prevent follicle loss, due to its potentiation effect on IGF-1/IGF-1R-mediated antioxidant and cytoprotection (18). IGF-1 generally stimulates differentiation and proliferation of granulosa cells. $(19,20,29)$ and prevents apoptosis and follicular atresia (12, 14). Therefore, according to our study, we hypothesize that decreasing IGF-1 in the granulosa cells may lead to atresia and suppress the growth of these follicles. We found that IGF1 expression in intersititial cells was significantly increased in the high dose group compared to the other groups. Rzepczynska et al. (31) demonstrated that the increase of IGF-1 expression in interstitial cells is directly related to the polycystic ovary syndrome. We suggest that the increased IGF-1 expression in interstitial cells and presence of cystic structures in the experimental groups may be related to the polycystic ovary syndrome. We found no significant difference in IGF-1 expression in theca cells and corpus luteum, suggesting that TAM does not affect IGF-1 expression in these structures.

Also, expression of IGF- IR was detected in the oocyte cytoplasm, granulosa cells and theca cells of all follicles, interstitial cells and corpus luteum in control group. In our study IGF-1R expressions in oocytes are consistent with previous studies $(44,28)$. IGF-1R expression was detected in the granulosa cells of human and various animal species $(15,39,44)$. We observed that IGF-1R immunoreactivity varied from weak to strong depending on follicle development in granulosa cells of all groups. In the present study, the strongest IGF-1R immunoreactions were observed in the antral follicles of the low dose TAM groups. These data suggest that TAM suppresses IGF-1 expression in the large follicles while increasing IGF-1R expression. Similar to our study, previous studies have reported an inverse correlation between IGF-1 and IGF-1R levels (9, 11, 36, 43). Our observations of IGF-1R expression are consistent with previous studies of corpus luteum (25), theca cells (34) and interstitial cells (44). The present study we observed that TAM causes an increase in the expression of both IGF-1 and IGF-1R in interstitial cells. Terada et al. (35) reported that TAM directly affects the ovary by increasing 
the level of estradiol and showing estrogen agonist effect. Given that interstitial cells play an active role in estrogen synthesis (6), as reported by Terada et al. (35), we speculate that TAM may have a stimulatory function on estrogen synthesis by increasing IGF-1 and IGF-1R expressions. In the present study, IGF-1R immunoreactions in corpus luteum were significantly decreased in the treatment group compared to the control group. This decrease may be due to the hyperestrogenic effect of TAM.

As a result, we showed that TAM changes the IGF-1 and IGF-1R expressions in the ovary in a dose-dependent manner. TAM may stimulate IGFs in ovarian follicles and show an agonist effect on estrogen, leading to polycystic ovary syndrome in mice. Therefore, use of IGF-1 signaling pathway regulators may be considered to counteract the adverse effects of TAM on the ovary.

\section{Acknowledgments}

This work was supported by the Scientific and Technological Research Council of Turkey (TÜBİTAK Project No: 1170695).

\section{Conflict of Interest}

The authors declared that there is no conflict of interest.

\section{References}

1. Akduman AT, Özerkan K, Zik B, et al (2014): Effect of tamoxifen on ovarian reserve: A randomized controlled assessor-blind trial in a mouse model. J Turk Ger Gynecol Assoc, 15, 228-232.

2. Akkaya OO, Altunbas K, Yagel A (2017): Effects of methoxychlor on IGF-1 signaling pathway in rat ovary. Biotech Histochem, 92, 230-242.

3. Armstrong DG, Gutierrez CG, Baxter G, et al (2000): Expression of $m R N A$ encoding IGF-1, IGF-1I and type 1 IGF receptor in bovine ovarian follicles. J Endocrinol, 165, 101-113.

4. Armstrong DG, Webb R (1997): Ovarian follicular dominance: the role of intraovarian growth factors and novel proteins. Rev Reprod, 2, 139-146.

5. Baumgarten SC, Convissar SM, Fierro MA, et al (2014): IGF1R signaling is necessary for FSH-induced activation of $A K T$ and differentiation of human cumulus granulosa cells. J Clin Endocrinol Metab, 99, 2995-3004.

6. Cara JF, Rosenfield RL (1988): Insulin-like growth factor $I$ and insulin potentiate luteinizing hormone-induced androgen synthesis by rat ovarian thecal-interstitial cells. Endocrinology, 123, 733-739.

7. Cohen I, Figer A, Tepper R, et al (1999): Ovarian overstimulation and cystic formation in premenopausal tamoxifen exposure: comparison between tamoxifen treated and nontreated breast cancer patients. Gynecol Oncol, 72, 202-207.
8. Crossman G (1937): A modification of Mallory's connective tissue stain with a discussion of the principles involved. Anat Rec, 69, 33-38.

9. Cruickshank J, Grossman DI, Peng RK, et al (2005): Spatial distribution of growth hormone receptor, insulinlike growth factor-I receptor and apoptotic chondrocytes during growth plate development. J Endocrinol, 184, 543553.

10. Ergin K, Gursoy E, Baġımoğlu-Koca Y, et al (2008): Immunohistochemical detection of insulin-like growth factor-I, transforming growth factor-b2, basic fibroblast growth factor and epidermal growth factor-receptor expression in developing rat ovary. Cytokine, 43, 209-214.

11. Fu Z, Noguchi T, Kato H (2001): Vitamin a deficiency reduces insulin-like growth factor (IGF)-I gene expression and increases IGF-1 receptor and insulin receptor gene expression in tissues of japanese quail (coturnix coturnix japonica). J Nutr, 131, 1189-1194.

12. Guthrie HD, Garrett WM, Cooper BS (1998): Folliclestimulating hormone and insulin-like growth factor-I attenuate apoptosis in cultured porcine granulosa cells. Biol Reprod, 58, 390-396.

13. Higgins MJ, Baselga J (2011): Targeted therapies for breast cancer. J Clin Invest, 121, 3797-3803.

14. Hu CL, Cowan RG, Harman RM, et al (2004): Cell cycle progression and activation of akt kinase are required for insulin-like growth factor I-mediated suppression of apoptosis in granulosa cells. Mol Endocrinol, 18, 326-338.

15. Kwintkiewicz J, Giudice LC (2009): The interplay of insulin-like growth factors, gonadotropins, and endocrine disruptors in ovarian follicular development and function. Semin Reprod Med, 27, 43-51.

16. Luigi LD, Conti FG, Casini A (1997): Growth hormone and insulin-like growth factor I responses to moderate submaximal acute physical exercise in man: effects of octreotide, a somatostatin analogue, administration. Int J Sports Med, 18, 257-263.

17. Macgregor JI, Jordan C (1998): Basic guide to the mechanisms of antiestrogens. Pharmacol Rev, 50, 151-196.

18. Mahran YF, El-Demerdash E, Nada AS, et al (2013): Insights into the protective mechanisms of tamoxifen in radiotherapy-induced ovarian follicular loss: Impact on insulin-like growth factor 1. Endocrinology, 154, 38883899.

19. Mazerbourg S, Bondy CA, Zhou J, et al (2003): The insulin-like growth factor system: a key determinant role in the growth and selection of ovarian follicles? a comparative species study. Reprod Domest Anim, 38, 247-258.

20. Monget $\mathbf{P}$, Fabre S, Mulsant $\mathbf{P}$, et al (2002): Regulation of ovarian folliculogenesis by IGF and BMP system in domestic animals. Domest Anim Endocrinol, 23, 139-154.

21. Monniaux D, Pisselet C (1992): Control of proliferation and differentiation of ovine granulosa cells by insulin-like growth factor-I and follicle-stimulating hormone in vitro. Biol Reprod, 46, 109-119.

22. Mourits MJE, Vries EGE, Willemse PHB, et al (1999): Ovarian cysts in women receiving tamoxifen for breast cancer. Br J Cancer, 79, 1761-1764.

23. O'Regan RM, Cisneros A, England GM, et al (1998): Effects of the antiestrogens tamoxifen, toremifene, and ICI 
182,780 on endometrial cancer growth. J Natl Cancer Inst, 90, 1552-1558.

24. Pasqualini JR, Sumida C, Giambiagi N (1998): Pharmacodynamic and biological effects of anti-estrogens in different models. J Steroid Biochem, 31, 613-643.

25. Perks CM, Peters AR, Wathes DC (1999): Follicular and luteal expression of insulin-like growth factors I and II and the type 1 IGF receptor in the bovine ovary. J Reprod Fertil, 116, 157-165.

26. Pollak MN, Huynh HT, Lefebvre SP (1992): Tamoxifen reduces serum insulin-like growth factor I (IGF-1). Breast Cancer Res Treat, 22, 91-100.

27. Qu J, Godin PA, Nisolle M, et al (2000): Expression of receptors for insulin-like growth factor-I and transforming growth factor- $\beta$ in human follicles. Mol Hum Reprod, 6 , 137-145.

28. Quirk SM, Cowan RG, Harman RM, et al (2004): Ovarian follicular growth and atresia: the relationship between cell proliferation and survival. J Anim Sci, 82, 4052.

29. Ramachandran C, Khatib Z, Petkarou A, et al (2004): Tamoxifen modulation of etoposide cytotoxicity involves inhibition of protein kinase $C$ activity and insulin-like growth factor II expression in brain tumor cells. $\mathbf{J}$ Neurooncol, 67, 19-28.

30. Rzepczynska IJ, Piotrowski PC, Wong DH, et al (2009): Role of isoprenylation in Simvastatin-Induced inhibition of ovarian theca-interstitial growth in the rat. Biol Reprod, 81, 850-855.

31. Sherman BM, Chapler FK, Crickard K, et al (1979): Endocrine consequences of continuous antiestrogen therapy with tamoxifen in premenopausal women. J Clin Invest, 64, 398-404.

32. Shushan A, Peretz T, Uziely B, et al (1996): Ovarian cysts in premenopausal and postmenopausal tamoxifen-treated women with breast cancer. Am J Obstet Gynecol, 174, 141144.

33. Spicer LJ, Chamberlain CS (1998): Influence of cortisol on insulin-and insulin-like growth factor 1 (IGF-1)-induced steroid production and on IGF-1 receptors in cultured bovine granulosa cells and thecal cells. Endocrine, 9, 153161.
34. Terada S, Uchide K, Suzuki N (1993): A follicular cyst during tamoksifen therapy in a premenopausal breast cancer woman. Gynecol Obstet Invest, 35, 62-64.

35. Thissen JP, Ketelslegers JM, Underwood LE (1994): Nutritional regulation of the insulin-like growth factors. Endocr Rev, 15, 80-163.

36. Ting AY, Kimler BF, Fabian CJ, et al (2008): Tamoxifen prevents premalignant changes of breast but not ovarian cancer in rats at high risk for both diseases. Cancer Prev Res, (Phila) 1, 546-553.

37. Ting AY, Petroff BK (2010): Tamoxifen decreases ovarian follicular loss from experimental toxicant DMBA and chemotherapy agents cyclophosphamide and doxorubicin in the rat. J Assist Reprod Genet, 27, 591-597.

38. Toda K, Miyaura C, Okada T, et al (2002): Dietary bisphenol a prevents ovarian degeneration and bone loss in female mice lacking the aromatase gene (Cyp19). Eur J Biochem, 269, 2214-2222.

39. Tsujioka S, Ban Y, Wise LD, et al (2009): Collaborative work on evaluation of ovarian toxicity. 3) Effects of 2- or 4week repeated dose toxicity and fertility studies with tamoksifen in female rats. J Toxicol Sci, 34, 43-51.

40. Tucker MJ, Adam HK, Patterson JS (1984): Tamoxifen. 125-161. In: DR Laurence, AEM McLean, M Wetherall (Eds), Safety Testing of New Drugs, Laboratory Predictions and Clinical Performance. Academic. Press, London.

41. Wandji SA, Wood TL, Crawford J, et al (1998): Expression of mouse ovarian insulin growth factor system components during follicular development and atresia. Endocrinology, 139, 5205-5214.

42. Werner H, Shen-Orr Z, Stannard B, et al (1990): Experimental diabetes increases insulinlike growth factor I and II receptor concentration and gene expression in kidney. Diabetes, 39, 1490-1497.

43. Zhou J, Chin E, Bondy C (1991): Cellular pattern of insulin-like factor-I (IGF-1) and IGF-1 receptor gene expression in the developing and mature ovarian follicle. Endocrinology, 129, 3281-3288.

44. Zhou P, Baumgarten SC, Wu Y, et al (2013): $I G F-1$ signaling is essential for FSH stimulation of AKT and steroidogenic genes in granulosa cells. Mol Endocrinol, 27, 511-523. 